\title{
PERAN PENDIDIKAN AGAMA ISLAM \\ DALAM KELUARGA DAN MASYARAKAT
}

\author{
Udin Solehudin \\ Email : solehudinu@gmail.com \\ Universitas Islam Al-Ihya Kuningan
}

\begin{abstract}
ABSTRAK
Pendidikan dalam keluarga merupakan aspek penting dalam pembentukan perilaku seseorang. Pada umumnya pendidikan dalam keluarga dilakukan dengan menanamkan nilai-nilai agama, etika yang meliputi budi perkerti, cara, tingkah laku yang harus dilakukan dalam kehidupan sehari-hari. Penulisan ini bertujuan untuk mengetahui dan membahas peran pendidikan agama Islam dalam keluarga dan masyarakat. Metode penulisan ini adalah kajian kepustakaan dengan pendekatan deskriptif dan eksploratif. Dapat disimpulan bahwa peran pendidikan agama Islam merupakan: (1) fondasi dalam keluarga untuk membentuk perilaku dan moral anakanak dan mengetahui batasan baik dan buruk, (2) berfungsi untuk membentuk manusia yang percaya dan ketaqwaan kepada Allah SWT, (3) fondasi utama dan berperan dalam pendidikan moral bagi pembangunan masyarakat Indonesia seluruhnya.
\end{abstract}

Kata kunci : pendidikan agama Islam, keluarga, masyarakat

\begin{abstract}
Education in the family is an important aspect to build a person's behavior. Usually the education in a family is condacted with the religious values and ethics, which consists of behavior, manners and use attitude used in everydays life. The aim of this writing is to discuss the role of religious education in the family and society. This method used library research with the descriptive and explorative approach. The conclusions are that the role of the Islamic education: (1) as the foundation of religious education in a family which used to form the children' good attitude and behavior, (2) functions as tools to convince people to the almighty of God, (3) as a foundation to build the society character for the Indonesian people to improve the nation.
\end{abstract}

Key words : Islamic education, family, society

\section{PENGANTAR}

Latar belakang penulisan makalah ini adalah seringnya terjadi berbagai peristiwa kekerasan seperti tawuran antar pelajar yang penyebabnya dipicu hanya soal yang tidak terlalu penting tetapi mengakibatkan korban, baik yang luka maupun meninggal. Demikian pula masalah lainnya yang menyangkut peserta didik dan masyarakat umum seperti adanya geng motor yaitu sekumpulan anak-anak remaja yang mempunyai hobi bermotor yang melakukan tindakan kekerasan, penganiayaan, penjambretan hingga perampokan yang sangat meresahkan masyarakat. Kejadian-kejadian tersebut menimbulkan pertanyaan bagaimana peran pendidikan dalam membentuk pola pikir dan tingkah laku atau moral peserta didik maupun masyarakat umum dan bangsa. 
Pendidikan tidak dapat dipisahkan dari kehidupan keluarga, sekolah dan masyarakat. Sesuai dengan pendapat Hadirah (2008;5), bahwa Pendidikan sangat berperan penting dalam kehidupan manusia; tanpa pendidikan, manusia tak berdaya. Pada dasarnya pendidikan adalah usaha orang tua atau generasi tua untuk mempersiapkan anak atau generasi mudanya agar nantinya dapat hidup secara mandiri dan mampu melaksanakan tugas-tugas dalam hidupnya secara baik. Dalam UU Nomor 20 Tahun 2003 tentang Sistem Pendidikan Nasional Pasal 3, bahwa: "Pendidikan Nasional berfungsi mengembangkan kemampuan dan membentuk watak serta peradaban bangsa yang bermartabat dalam rangka mencerdasknn kehidupan bangsa, bertujuan untuk berkembangnya potensi peserta didik agar menjadi manusia yang: beriman dan bertaqwa kepada Tuhan YME, beraklak mulia, sehat, berilmu, kreatif, mandiri dan menjadi warga negara yang demokratis serta bertanggung jawab”

Pendidikan berupaya mendidik manusia untuk mempunyai ilmu pengetahuan dan keterampilan disertai dengan Iman dan Taqwa kepada Allah SWT, sehingga dia akan memanfaat kan ilmu pengetahuan dan ketrampilan yang dimilikinya itu untuk kebaikan masyarakat, lingkungan dan bangsanya.

Menurut Zuhairini (1983:27) bahwa "pendidikan agama ialah usaha-usaha secara sistematis dan pragmatis untuk membantu anak didik agar mereka hidup sesuai dengan ajaran agama". Sementara menurut Zakiah (1990:46) pendidikan agama Islam adalah sebagai berikut : "Pendidikan dengan melalui ajaran-ajaran agama Islam, yaitu bimbingan dan asuhan terhadap anak didik agar nantinya setelah selesai ia dapat memahami, menghayati dan mengamalkan ajaran-ajaran agama Islam yang telah diyakininya secara menyeluruh, serta menjadikan ajaran agama Islam itu sebagai suatu pandangan hidupnya demi keselamatan dan kesejahteraan hidup di dunia dan di akhirat kelak".

Dengan demikian pendidikan agama merupakan suatu usaha bimbingan dan asuhan terhadap anak didik agar nantinya dapat mengamalkan ajaran agamanya. Jadi dalam pendidikan agama yang lebih dipentingkan adalah sebagai pembentukan kepribadian anak, yaitu menanamkan tabiat yang baik agar anak didik mempunyai sifat yang baik dan berkepribadian yang utama.

Tujuan pendidikan agama adalah: (1) terbentuknya kepribadian yang utuh jasmani dan rohani (insan kamil) yang tercermin dalam pemikiran maupun tingkah laku terhadap sesama manusia, alam serta Tuhannya, (2) dapat menghasilkan manusia yang tidak hanya berguna bagi dirinya, tapi juga berguna bagi masyarakat dan lingkungan, serta dapat mengambil manfaat yang lebih maksimal terhadap alam semesta untuk kepentingan hidup di dunia dan akhirat, (3) merupakan sumber daya pendorong dan pembangkit bagi tingkah laku dan perbuatan yang baik, dan juga merupakan pengendali dalam mengarahkan tingkah laku dan perbuatan manusia. Oleh karena itu pembinaan moral harus didukung pengetahuan tentang ke-Islaman pada umumnya dan aqidah atau keimanan pada khususnya.

Pendidikan agama merupakan faktor yang sangat penting untuk menyelamatkan anakanak, remaja ataupun orang dewasa dari pengaruh buruk budaya asing yang bertentangan dengan budaya Islam yang saat ini sudah banyak mempengaruhi bangsa Indonesia, terutama generasi muda.

Menurut pandangan Islam, pendidikan harus mengutamakan pendidikan keimanan. Sejarah telah membuktikan bahwa pendidikan yang tidak atau kurang memperhatikan pendidikan keimanan akan menghasilkan lulusan yang kurang baik akhlaknya. Akhlak yang rendah itu akan sangat berbahaya bagi kehidupan bersama yang dapat menghancurkan sendi-sendi kehidupan berbangsa 
dan bernegara. Lulusan sekolah yang kurang kuat imannya akan sangat sulit menghadapi kehidupan pada zaman yang semakin penuh tantangan di masa mendatang.

Oleh karena itu, mengingat pentingnya pendidikan Islam terutama bagi generasi muda, semua elemen bangsa, terutama guru pendidikan Islam, perlu membumikan kembali pendidikan Islam di sekolah-sekolah baik formal maupun informal (Suharsimi; 2009:117). Permasalahannya adalah bagaimana peran keluarga dan masyarakat dalam meningkatkan keimanan dan kecerdasan melalui pendidikan agama.

Penulisan ini bertujuan untuk mengetahui : (1) bagaimana peran pendidikan agama dalam keluarga dan masyarakat, serta (2) manfaat pendidikan dalam lingkungan masyarakat. Metode penulisan menggunakan studi kepustakaan, dengan pendekatan deskriptif eksploratif.

\section{PEMBAHASAN}

\section{Pendidikan}

Pendidikan bertujuan untuk meningkatkan kualitas sumber daya manusia. Salah satu usaha untuk meningkatkan kualitas sumber daya manusia adalah melalui proses pembelajaran di lembaga pendidikan, dari tingkat anak usia dini sampai pada usia pendidikan tinggi. Menurut Zuchdi (2010:2-3) bahwa Pendidikan adalah usaha sadar dan terencana untuk mewujudkan suasana belajar dan proses pembelajaran agar peserta didik secara aktif mengembangkan potensi dirinya untuk memiliki kekuatan spiritual keagamaaan, pengendalian diri, kepribadian, kecerdasan, akhlak mulia, serta ketrampilan atau karakter yang diperlukan dirinya, masyarakat, bangsa, dan Negara. Secara akademis, pendidikan karakter dimaknai sebagai pendidikan nilai, budi pekerti, moral, watak, atau akhlak yang bertujuan untuk mengembangkan kemampuan peserta didik memberikan keputusan baikburuk, memelihara apa yang baik itu dan mewujudkannya dalam kehidupan sehari-hari.

Dengan demikian Pendidikan merupakan kata kunci untuk setiap manusia agar ia mendapatkan ilmu. Hanya dengan pendidikanlah ilmu akan didapat dan diserap dengan baik. Menurut Ratna Wilis (2006:98) bahwa Pendidikan juga merupakan metode pendekatan yang sesuai dengan fitrah manusia yang memiliki fase tahapan dalam pertumbuhan. Selanjutnya tujuan pendidikan berkaitan erat dengan tujuan hidup manusia, dan tujuan hidup ini pun berbedabeda antara bangsa yang satu dengan yang lainnya.

\section{Pendidikan Agama Islam}

Menurut Arifin Muzayyin (2010;34) : Tujuan Pendidikan Keagamaan adalah untuk mempersiapkan peserta didik agar dapat menjalankan peranan yang menuntut penguasaan pengetahuan khusus tentang ajaran agama yang bersangkutan. Seiring dengan perkembangan waktu, maka Pendidikan Agama semakin menjadi perhatian dengan pengertian bahwa pendidikan agama semakin dibutuhkan oleh setiap manusia terutama mereka yang masih duduk di bangku sekolah.

Pendidikan Islam memiliki 3 (tiga) tahapan kegiatan yaitu: (1) Tilawah ; membacakan ayat Allah, (2) Tazkiyah ; mensucikan jiwa, (3) Ta'limul kitab wa sunnah ; mengajarkan al kitab dan al hikmah. Pendidikan agama dapat merubah masyarakat jahiliyah menjadi umat yang baik. Pendidikan Islam mempunyai ciri pembentukan pemahaman Islam yang utuh dan menyeluruh, pemeliharaan apa yang telah dipelajarinya, pengembangan atas ilmu yang diperolehnya dan agar tetap pada rel syariah. Hasil dari pendidikan Islam akan membentuk jiwa yang tenang, akal yang cerdas dan fisik yang kuat serta banyak beramal. 
Pendidikan Islam terpadu dalam pendidikan ruhiyah, fikriyah dan amaliyah (aktivitas). Nilai Islam yang ditanamkan pada individu membutuhkan tahapan-tahapan selanjutnya dan dikembangkan pada pemberdayaan di segala sektor kehidupan manusia. Potensi yang dikembang kan kemudian diarahkan pada merealisasikan potensi dalam berbagai kehidupan. Pendidikan yang diajarkan Allah SWT melalui Rasul-Nya bersumber kepada Al Qur'an sebagai rujukan dan pendekatan agar dengan tarbiyah akan membentuk masyarakat yang sadar dan menjadikan Allah sebagai Ilah saja, maka kehidupan mereka akan selamat di dunia dan akhirat. Hasil ilmu yang diperolehnya adalah kenikmatan yang besar, yaitu berupa pengetahuan, harga diri, kekuatan dan persatuan.

\section{Tujuan Utama Pendidikan Islam}

Tujuan utama dalam pendidikan Islam adalah agar manusia memiliki gambaran tentang Islam yang jelas, utuh dan menyeluruh. Interaksi di dalam diri manusia memberi pengaruh kepada penampilan, sikap, tingkah laku dan amalnya sehingga menghasilkan akhlaq yang baik. Akhlaq ini perlu dan harus dilatih melalui latihan membaca dan mengkaji Al Qur'an, sholat malam, shoum (puasa) sunnah, selalu ber silaturahim dengan keluarga dan masyarakat. Semakin sering ia melakukan latihan, maka semakin banyak amalnya dan semakin mudah ia melakukan kebajikan. Selain itu latihan akan menghantarkan dirinya memiliki kebiasaan yang akhirnya menjadi gaya hidup sehari-hari.

\section{Langkah- langkah Menanamkan Pendidikan Islam}

Al-Qurthubi menyatakan bahwa ahli-ahli agama Islam membagi tiga tingkatan pengetahuan yaitu : (1) pengetahuan tinggi ; ilmu ketuhanan, (2) pengetahuan menengah; mengenai dunia seperti kedokteran dan matematika, (3) pengetahuan rendah; pengetahuan praktis seperti bermacam-macam keterampilan kerja. Hal ini berarti bahwa pendidikan iman/agama harus diutamakan.

Tiga hal penting yang harus secara serius dan konsisten diajarkan kepada anak didik yaitu : (1) Pendidikan akidah/keimanan; untuk menghasilkan generasi muda masa depan yang tangguh dalam imtaq (iman dan taqwa) dan terhindar dari aliran atau perbuatan yang menyesat kan kaum remaja seperti gerakan Islam radikal, penyalagunaan narkoba, tawuran dan pergaulan bebas (freesex) yang akhir-akhir ini sangat mengkhawatirkan, (2) Pendidikan ibadah; untuk diajarkan kepada anak-anak untuk membangun generasi muda yang punya komitmen dan terbiasa melaksanakan ibadah, seperti shalat, puasa, membaca Al-Quran. Peran orang tua dan guru sangat diperlukan dalam memberikan contoh dan teladan yang baik bagi anak-anak dan peserta didik, (3) Pendidikan akhlakul-karimah; untuk melahirkan generasi rabbani, atau generasi yang bertaqwa, cerdas dan berakhlak mulia. Oleh karena itu peran para orang tua dan pendidik baik di lingkungan sekolah maupun di luar sekolah sangat dibutuhkan.

Penanaman pendidikan Islam bagi generasi muda bangsa tidak akan dapat berjalan secara optimal dan konsisten tanpa dibarengi keterlibatan serius dari semua pihak. Oleh karena itu, semua elemen bangsa (pemerintah, tokoh agama, masyarakat, pendidik, orang tua dan sebagainya) harus memiliki niat dan perhatian yang serius agar generasi masa depan bangsa Indonesia adalah generasi yang berintelektual tinggi dan berakhlak mulia.

\section{Pendidikan Agama dalam Keluarga}

Keluarga menduduki posisi terpenting di antara lembaga-lembaga sosial yang memiliki perhatian terhadap pendidikan anak. Biasanya dalam keluarga ditanamkan nilai-nilai agama untuk membentuk perilaku anak. Oleh karena itu, pendidikan agama dalam keluarga sangat diperlukan untuk mengetahui batasan-batasan baik danburuk dalam kehidupan sehari-hari. 
Pendidikan agama diharapkan akan mendorong setiap manusia untuk mengerjakan sesuatu dengan suara hatinya.

Mengingat pentingnya pendidikan keluarga dalam membangun sumber daya manusia (SDM) yang berakhlak dan bermoral, maka perlunya pemahaman tentang pendidikan yang tepat.

\section{Peran Keluarga dalam Pendidikan}

Menurut etimologi peran keluarga dalam pertumbuhan anak ibarat baju besi yang kuat yang melindungi manusia. Secara terminologis, keluarga berarti sekelompok orang yang pertama berinteraksi dengan bayi. Pada tahun-tahun pertama hidup bayi bersama keluarga. Bayi tumbuh dan berkembang mengikuti kebiasaan dan tingkah laku orang tua dan orang-orang sekitamya.

Psikolog dan ahli pendidikan meyakini bahwa keluarga merupakan faktor utama yang mampu memberikan pengaruh terhadap pembentukan dan pengaturan ahklak anak. Keluarga terus memiliki pengaruh di masa kanakkanak saat anak selesai sekolah, sampai anak itu lepas dari pengasuhan dan mengarungi bahtera rumah tangganya.

Peran Keluarga adalah : (1) merupakan lembaga pendidikan pertama dan utama karena dalam keluargalah manusia dilahirkan, berkembang dan menjadi dewasa. Pendidikan di dalam keluarga sangat mempengaruhi tumbuh dan terbentuknya watak, budi pekerti dan kepribadian tiap-tiap manusia, (2) ibarat sekolah pertama dimasuki anak sebagai pusat untuk menumbuh kembangkan kebiasaan (tabiat), mencari pengetahuan dan pengalaman, (3) perantara untuk membangun kesempurnaan akal anak dan kedua orang tuanya yang bertanggung jawab untuk mengarahkan serta membangun dan mengembangkan kecerdasan berpikir anak. Semua sikap, perilaku dan perbuatan kedua orang tua selalu menjadi perhatian anak-anak.

Fungsi-fungsi utama keluarga yaitu : (1) Menjaga fitrah anak yang luhur dan suci, (2) Meluruskan fitrahnya dan membangkitkan serta mengembangkan bakat kemampuan positifnya, (3) Menciptakan lingkungan yang aman dan tenang dan mengasuhnya di lingkungan yang penuh kasih sayang, lemah lembut dan saling mencintai. Dengan demikian anak tersebut memiliki kepribadian normal yang mampu melaksanakan kewajiban dan berguna di masyarakat, (4) memberikan informasi tentang pendidikan dan kebudayaan masyarakat, bahasa, adat istiadat dan norma-norma sosial agar anak dapat mempersiapkan kehidupan sosialnya dalam masyarakat.

Untuk itu keluarga perlu : (1) memupuk bakat dan kemampuan anak dalam mencapai perkembangan yang baik, (2) menyediakan lingkungan yang efektif dan kesempatan untuk menumbuhkan kecerdasan emosional, tingkah laku, sosial kemasyarakatan dan kecerdasan intelegensi. (3) memberikan kenyamanan dan ketenangan, serta mampu memahami gerakan, isyarat, dan kebutuhan anak, (4) memberikan jawaban yang tepat atas pertanyaanpertanyaan anak pada waktu yang tepat. (5) menumbuhkankepekaan kesadaran bermasyarakat pada anak yang merupakan salah satu unsur kejiwaan, seperti nurani. Kepekaan kesadaran masyarakat itu terus tumbuh di dalam jiwa anak dalam kedisiplinan keluarga.

\section{Peran Masyarakat dalam Pendidikan.}

Masyarakat adalah sekumpulan orang dengan berbagai ragam kualitas diri mulai dari yang tidak berpendidikan sampai pada yang berpendidikan tinggi. Kualitas suatu masyarakat ditentukan oleh kualitas pendidikan para anggotanya, makin baik pendidikan anggotanya, semakin baik pula kualitas masyarakat secara keseluruhan. Masyarakat merupakan lembaga pendidikan yang ketiga setelah pendidikan di lingkungan keluarga dan lingkungan sekolah.

Pada Sistem pendidikan nasional tercantum bahwa dalam rangka membangun masyarakat lndonesia seutuhnya, pada hakikatnya menjadi tanggung jawab seluruh bangsa lndonesia dan dilaksanakan oleh keluarga, masyarakat dan pemerintah. Hal ini juga ditegaskan dalam Rencana 
Pembangunan Lima Tahun pemerintah. Masyarakat ikut bertanggung jawab atas berbagai permasalahan pendidikan. Masyarakat diberikan kesempatan untuk berpartisipasi, sebagaimana tertera dalam Undang-Undang Sisdiknas Nomor 20 Tahun 2003 pasal 8 bahwa; masyarakat berhak berperan serta dalam perencanaan, pelaksanaan, pengawasan dan evaluasi program pendidikan.

Tujuan dari pasal ini adalah agar dapat menjamin pemerataan kesempatan dan kualitas pendidikan. Dengan demikian masyarakat mempunyai peran yang besar dalam pelaksanaan pendidikan nasional antara lain menciptakan suasana yang dapat menunjang pelaksanaan pendidikan dan ikut melaksanakan pendidikan non pemerintah (swasta).

\section{Peran Pendidikan Agama di Lingkungan Masyarakat}

Menurut H. Jalaluddin : beberapa fungsi agama dalam masyarakat, antara lain : (1) fungsi Edukatif (Pendidikan); ajaran agama secara yuridis (hukum) berfungsi menyuruh/mengajak dan melarang yang harus dipatuhi agar pribagi penganutnya menjadi baik dan benar, dan terbiasa dengan yang baik dan yang benar menurut ajaran agama masing-masing.(2) fungsi Penyelamat; dimanapunmanusia berada, dia selalu menginginkan dirinya selamat. Keselamatan yang diberikan oleh agama meliputi kehidupan dunia dan akhirat. (3). fungsi Perdamaian; melalui tuntunan agama seorang/sekelompok orang yang bersalah atau berdosa mencapai kedamaian batin dan perdamaian dengan diri sendiri, sesama, semesta dan Allah, (4) fungsi Kontrol Sosial; ajaran agama membentuk penganutnya semakin peka terhadap masalah-masalah sosial seperti, kemaksiatan, kemiskinan, keadilan, kesejahteraan dan kemanusiaan. Kepekaan ini juga mendorong untuk tidak dapat berdiam diri menyaksikan kebatilan yang merasuki sistem kehidupan yang ada, (5) fungsi Pemupuk Rasa Solidaritas; bila fungsi ini dibangun secara serius dan tulus, maka persaudaraan yang kokoh akan berdiri tegak menjadi pilar "Civil Society" (kehidupan masyarakat) yang memukau, (6) fungsi Pembaharuan; ajaran agama dapat mengubah kehidupan pribadi seseorang atau kelompok menjadi kehidupan baru. Dengan fungsi ini seharusnya agama terus-menerus menjadi agen perubahan basis-basis nilai dan moral bagi kehidupan bermasyarakat, berbangsa dan bernegara, (7) fungsi Kreatif; menopang dan mendorong fungsi pembaharuan untuk mengajak umat beragama bekerja produktif dan inovatif bukan hanya bagi diri sendiri tetapi juga bagi orang lain, (8) fungsi Sublimatif (bersifat perubahan emosi); ajaran agama mensucikan segala usaha manusia, bukan saja yang bersifat agamawi, melainkan juga bersifat duniawi. Usaha manusia dapat dilakukan selama tidak bertentangan dengan norma-norma agama dan atas niat yang tulus. Dengan demikian Pendidikan agama dalam lingkungan masyarakat sangat berperan penting bagi kehidupan bermasyarakat dan dalam meningkatkan moral bangsa dan Negara.

\section{KESIMPULAN}

1. Pendidikan agama Islam berfungsi dalam keluarga dan masyarakat untuk membentuk manusia yang percaya dan ketaqwaan kepada Allah SWT agar terciptanya kehidupan yang baik dalam keluarga dan masyarakat.

2. Pendidikan agama Islam merupakan fondasi yang utamasebagai sistem pendidikan moral dan ahklak, dalam rangka pembangunan manusia Indonesia seutuhnya dan masyarakat Indonesia seluruhnya.

3. Pendidikan agama dalam lingkungan masyarakat sangat berperan penting bagi kehidupan bermasyarakat dan untuk meningkatkan moral bangsa dan Negara. 


\section{Saran-saran}

1. Agar pendidikan agama dapat dilaksanakan secara terarah dan terencana baik dalam keluarga dan masyarakat.

2. Perlu perhatian dan peran Pemerintan untuk membantu agar pendidikan agama dapat dilakukan secara serius di sekolah sehingga peserta didik memiliki ahlak mulia serta dapat meningkatkan kualitas sumber daya manusia yang mampu berperan mengembangkan Negara dan bangsa.

\section{REFERENSI}

Arifin Muzayyin. Filsafat Pendidikan Islam, Bumi Aksara, Jakarta,2010.

Barnawi dan Mohammad Arifin, Etika dan Profesi Pendidikan, ArRuzz Media, Yogyakarta, 2012

H. Jalaluddin, Psikologi Agama diunduh 30 Sept 2013 jam 15.30.

Hamdani, Ihsan, dan Fuad Ahmad, Filsafat Pendidikan Islam, Pustaka, Bandung,2007

Hadirah Ira, Dasar-dasar Kependidikan, UIN Alauddin.Makassar,2008

Ihsan Fuad. Ilmu Pendidikan, Cet. III, Rineka Cipta, Semarang, 2003

Ratna Wilis Dahar, Teori Belajar dan Pembelajaran, Erlangga, Jakarta,2006

Ratna Wilis Dahar, Dasar-Dasar Pendidikan Evaluasi Pendidikan, Bumi Aksara, Jakarta, 2009

Sukardi, Evaluasi Pendidikan, Bumi Aksara, Jakarta,2008

Tadjab, Perbandingan Pendidikan, Abditama, Surabaya, 1994.

Undang-Undang Republik Indonesia Nomor 12 Tahun 2013 Islam. diunduh pada Januari 2013 jam 20.00

Zainal Arifin \& Adhi Setiawan, Pengembangan Pembelajaran Aktif, Skripta,Yogyakarta,2012 